\title{
A Review and Comparative Analysis of the Russian Federation Government Quality Award
}

Purpose: The paper presents a review and comparison of the Russian Federation Government Quality Award (RFGQA) with the three major business excellence models, Malcolm Baldrige National Quality Award (MBNQA), European Foundation for Quality Management (EFQM) award and Deming Prize.

Design/Methodology/Approach: The paper briefly reviews the RFGQA through a desk-top research method. Then, it adapts the comparative approach used in a similar study by Vokurka et al. (2000). Thus, the comparative analysis consisted in contrasting two characteristics of the RFGQA with those of the MBNQA, EFQM award and Deming Prize, namely: award descriptors (i.e. objectives and criteria) and emphasis placed on excellence criteria (i.e. weighting). The study also includes a mapping assessment to explore up to what extent the RFGQA addresses the criteria of the major models.

Findings: Although the RFGQA was designed based on the concept and structure of the EFQM model, the results of the study indicate that there are still differences among them, especially in terms of internal business processes. RFGQA finds more differences with the MBNQA and Deming Prize excellence models than with the EFQM.

Practical Implications: This research would benefit organisations and managers in Russia as they will be able to acquire a deeper knowledge on the RFGQA. This may facilitate its awareness and implementation.

Originality/Value: The paper expands the current knowledge in the area of quality management and models for business excellence as it is among the very first investigations that have studied the RFGQA model.

Keywords: Business Excellence Models, Deming, EFQM, Malcom Baldrige, Quality, Russia

Paper Type: General Review

\section{Introduction}

Over the past decade there has been a continuous development of quality management practices through the creation and provision of quality awards, and the deployment of business excellence models (BEMs) (Adeyami et al., 2014). In this scenario, BEMs have played a significant role in the attempt to improve business performance among organisations (Rocha-Lona et al., 2009). These efforts are well documented by the Quality Foundations 
(i.e. European Foundation for Quality Management, the National Institute of Science and Technology, The Japanese Institute of Scientist and Engineers, the Canadian Quality Assurance Institute, among others) that administer BEMs across regions and countries. BEMs are quality management frameworks based on organisational performance criteria that originated as a result of the evolution of Total Quality Management (TQM) principles. Examples of BEMs include the Deming Prize (Japan) (Porter and Tanner, 2004), Malcolm Baldrige National Quality Award (US) (Porter and Taner, 1996; Oakland, 2001), the European Foundation for Quality Management award (Europe) (EFQM, 2013), among others. Nowadays, BEMs have been used by organisations, in over 83 countries (Mohammad et al., 2011), for national quality award participation, self-assessment, business processes improvement, benchmarking, sharing best practices and strategic planning (Jayamaha et al., 2011; Dahlgaard et al., 1998; Porter and Tanner, 2004).

Several research streams can be identified in the field of BEMs, with a large proportion of it being dedicated to measure the effect of BEMs on organisations' performance (i.e. financial, customer satisfaction, employee turnover, organisational growth, leadership and management, training, etc.) and its effective implementation within individual and across organisations (Kim et al., 2010). Similarly, other researches have focused on comparing BEMs against TQM constructs (Ghobadian and Woo, 1996), best practices (Everett et al., 1997) and an idealised criterion (Puay et al., 1998) in order to understand their definition and benchmark for business excellence. Along this line, researchers have also compared different BEMs. Table 1 present a summary of this research.

\section{$\underline{\text { Insert Table } 1 \text { in here }}$}

Despite the relatively high amount of research that has been undertaken to understand and compare different aspects of BEMs created and adopted by various nations around the world, see Table 1, scholar studies focused, particularly, on the Russian Business Excellence Model (RBEM) are almost non-existent. For instance, from all the comparative studies presented in Table 1, only the research conducted by Tan et al. (2003) considered the RBEM, arguing that it has mainly adopted the structure and criteria of the EFQM model. However, due to the nature and research approach taken by Tan et al. (2003), their study fails to provide a deeper insight into the RBEM and its similarities and differences in respect to, for example, the three major BEMs (i.e. EFQM, MBNQA and Deming Prize).

Currently, there is recognition from the Russian government and economic actors of this country that quality management is an important element to effectively compete in the global market and in a relatively open domestic market (Dickenson et al., 2000). Taking into consideration the lack of academic research on the RBEM and the importance placed on quality by the Russian government and organisations, this paper presents a study where the model for business excellence currently employed in Russia is reviewed and its objectives and criteria compared against the three major BEMs (Mavroidis et al., 2007; Miguel, 2001; Sharma and Talwar, 2007), in this case, the MBNQA, EFQM award and Deming Prize. Considering this, the main research questions that this paper addresses are:

RQ1. What are the main characteristics of the RBEM?

RQ2. What are the main differences and similarities between the RBEM and the Malcolm Baldrige National Quality Award, the European Foundation for Quality Management award and Deming Prize? 
The next sections address the two research questions as follow: Section 2 provides a brief review of the evolution of quality in Russia and the RBEM; Section 3 covers the research methodology followed within this paper and presents the framework employed to perform the comparison between the RBEM and the MBNQA, EFQM award and Deming Prize; the comparison as well as its results and discussion are outlined in Section 4; finally, Section 5 provides the conclusions, along with potential directions for further research.

\section{Quality in Russia and the Russian Business Excellence Model (RBEM)}

It is difficult to trace the roots of quality evolution in Russia, but prior to the creation of the RBEM in 1996, quality in this country was mainly assured through quality standards such as those developed by Kulikovsky in 1914/15, the Committee for Standardisation in the 1930s, and finally the Government Quality Standard (GOST) in the 1940s (Rebrin, 2004). Nowadays, Russia operates the System of National Standardisation, which is comprised of a series of interrelated rules and regulations that companies can followed to compete and improve the quality of innovations in the areas of the Russian economy regulated by the government. These rules and regulations are continuously refined and supplemented in connection with the purposes and principles of standardisation established by government law on technical regulations (Rebrin, 2004; GOST, 2014). However, despite the GOST series of quality standards has effectively contributed to the improvement of Russian products, services and processes (GOST, 2014), the transition to a market economy and the active inclusion of Russia into the global economic system forced the government to complement these standards with the creation of a BEM/quality award called the Russian Federation Government Quality Award (RFGQA).

The RBEM, in the form of the RFGQA, is administered by the Russian Government and regulated by Act No. 423 of April 12, 1996 (Russian Research Institute for Certification JSC, 2014). According to the Russian Research Institute for Certification JSC (2014a), the RFGQA's criteria are harmonised with that of the EFQM model. Rosstandart (2014) suggests that this harmonisation with the highly prestigious EFQM award provides Russian businesses with an innovative modern tool for development, improvement and competitiveness. In general, the RFGQA assumes that excellent performance in four result areas (i.e. employees' satisfaction; customer satisfaction with product/service; impact on society; and organisational results) is derived from five enablers/capabilities (i.e. leading role of top management; employees; organisational strategy \& quality policy; partnership \& resources; and processes, products and services). On this basis, the model is constituted by two main sections, namely enables/capabilities and results, which cover both tangible and intangible performance. Thus, employing the model, Russian organisations can measure their performance periodically, develop the relevant enablers, and develop both tangible and intangible-oriented performance indicators. In terms of the model's criteria scoring, the two sections (i.e. enablers/capabilities and results) allocate balanced weights $(50 \%-50 \%)$ between them. Figure 1 illustrates the RFGQA's structure.

\section{$\underline{\text { Insert Figure } 1 \text { in here }}$}

\section{Research Methodology}

The objective of this paper, as exemplified by RQ1 and RQ2, was to compare the RFGQA with the MBNQA, EFQM award, and the Deming Prize excellence model, which according to Mavroidis et al. (2007), Miguel (2001) and Sharma and Talwar (2007) can be considered 
the three major models for business excellence. To conduct this comparative study, an initial desk-top research, similar to that carried out by Grigg and Mann (2008a, 2008b, 2008c) and Saunders et al. (2008) when reviewing various aspects of business excellence models, was performed. The desk-top research consisted of reviewing international published research on the RFGQA, MBNQA, EFQM award, and the Deming Prize. In particular, literature was reviewed from 1995 forward and comprised: academic journal articles presenting comparative studies of excellence models; published guidelines of major award custodians; and those reviewing the characteristics, constituents, criteria and scoring of the four business excellence models considered in this study. Emphasis, however, was paid in reviewing the RFGQA.

In terms of the search strings, they were specified based on the four business excellence models under investigation. The C-I-M-O (context-intervention-mechanism-outcome) (Briner and Denyer, 2010; Rousseau, 2012) framework was followed during this phase of the desktop research to ensure the suitability of the published research considered for review. Thus, search strings included the name of the four business excellence models studied in both forms, full name and acronyms, as well as key words such as (comparison), (review), (structure), (scoring), etc. This allowed the definition of a specific search focus and the exclusion of articles when found that these did not refer to the inclusion of the key words that aligned to the objective of the study. In general, the desk-top research aided in obtaining a deep understanding of the business excellence models studied and selecting the framework employed to compare the RFGQA with the MBNQA, EFQM award, and the Deming Prize excellence models.

\subsection{Comparative Framework}

To conduct the comparative analysis, the approach developed by Vokurka et al. (2000) was adapted for the purpose of this research. Thus, the comparison was based on contrasting two specific characteristics of the RFGQA in relation to the same characteristics of the BNQA, EFQM and Deming Prize models. These characteristics included: (1) Award descriptors (i.e. objectives and criteria) and (2) Emphasis placed on excellence criteria (i.e. weighting). The summary and comparison of the models' objectives was performed to put into context the overall study. On the other hand, award criteria and the emphasis that BEMs place on them are considered two of the most important and distinctive elements of the models (Ghobadian and Woo, 1996; Jayamaha et al., 2011; Porter and Tanner, 1996). For this reason, these two characteristics were considered as comparative benchmarks. In addition, in order to complement the comparative study and gain a broader knowledge and insight into the differences and similarities of the RFGQA with regards to the MBNQA, EFQM and Deming Prize models, the study also included a mapping assessment of the MBNQA, EFQM and Deming Prize models on the RFGQA. Specifically, the objective of the mapping assessment was to explore up to what extent the RFGQA addresses the MBNQA, EFQM and Deming Prize models' criteria.

\section{Comparative Analysis, Results and Discussion}

\subsection{Award Descriptors}

Table 2 summarises the award descriptors, including objectives and award criteria, for the MBNQA, EFQM and Deming Prize models and that of the RFGQA. As shown in Table 2, the MBNQA, EFQM and Deming Prize models share similar objectives as all of them emphasise continuous analysis and improvement (Vokurka et al., 2000; Miguel, 2001). In the 
case of the RFGQA, its objective is also improvement-focused as it asserts the enhancement of products, services and business processes. In this case, however, the RFGQA not only recognises, in its stated objective, this award as a vehicle to achieve these improvements but also as a support tool for Russian businesses to become more competitive. In general terms, it could therefore be said that although the RFGQA's objective regarding continuous improvement is closely aligned to those of its international counterparts, this model goes beyond this objective by also be aimed at being used as a nation's wide approach to achieve international competitiveness. A similar objective is that of the EFQM model, which intends to "enhance the position of European industry and commerce by strengthening the strategic role of quality in corporations" (Ghobadian and Woo, 1996).

\section{Insert Table 2 in here}

On the other hand, Vokurka et al. (2000) and Miguel (2001) comment that the MBNQA, EFQM and Deming Prize models show, through their criteria, a customer-driven quality that can be achieved through fact-driven continuous improvement and learning (Porter and Tanner, 1996; Porter and Tanner, 2004), efficient business processes, human resource development, leadership, and a customer-focused strategic plan, integrated by an information and analysis system, all of them aiming at business results of various categories. In the case of the RFGQA, it is clear that its main objective is to improve the competitiveness of Russian organisations by monitoring and improving the same internal organisational aspects (i.e. leadership, staff, formulation of organisational \& quality strategies, etc.) as the three major models. Thus, similarly as the EFQM model in particular, the RFGQA recognises that there are different avenues to achieving excellence, and that an excellent balance of results is achieved by an effective leadership which drives strategies and policies through the continuous improvement of people, resources, partnerships and resources. Table 3 presents all the categories (i.e. criteria) emphasised by the three major BEMs and the RFGQA. As it can be clearly seen in Table 3, the RFGQA is harmonised with the EFQM model (Russian Research Institute for Certification JSC, 2014) and closely resembles the MBNQA. This can be explained by the desire of the Russian Government to comply with the quality standards of the European Union due to their close trading relations, where Russia is the third trading partner of the EU and the EU is the first trading partner of Russia (European Commission, 2014). In the case of the close similarities of the RFGQA with the MBNQA, these come from the similar definitions and constructs of excellence found in the EFQM and MBNQA.

\section{$\underline{\text { Insert Table } 3 \text { in here }}$}

Vokurka et al. (2000), Miguel (2001), Porter and Tanner (2004) suggest that the MBNQA, EFQM and Deming Prize models share seven common themes of excellence, namely, leadership, strategy and planning, customer focus, people focus, suppliers and partnerships, process management and results. Table 4 presents a comparative summary of how the award criteria of the RFGQA address these common themes in relation to those of the three major models.

\section{Insert Table 4 in here}




\subsection{Emphasis placed on excellence criteria}

Miguel (2001) comments that although the MBNQA, EFQM and Deming Prize have similarities in terms of being customer driven models of excellence that intend to satisfy customers' expectations through streamlining processes, leadership, human resource development and customer-focused strategic plans, they still have differences in terms of the emphasis (i.e. weight) they placed on each criteria. For example, customer satisfaction has the greatest weight for the EFQM model while business results have it for the MBNQA. Contrarily, all of the Deming Prize criteria are equally weighted. Figure 2 illustrates the criteria emphasis that the three major models, and the RFGQA, place on every one of the checkpoints. In the case of the RFGQA, its greatest emphasises are equally placed on customer satisfaction and business results. Despite the RFGQA was developed taking as a reference the EFQM and looking at its attuning with this model, it shows a different emphasis on the weighting of the criteria. In this case, the weighting distribution is more "uniform" than that of the EFQM as it gives a weight of 10 percent to every criteria, except to the greatest ones (i.e. customer satisfaction and business results). These are given a weight of 15 percent. This indicates that although the RFGQA's design base is that of the EFQM model, it was still adapted to the specific economic situation and needs of Russian organisations as well as their quality maturity. This may provide Russian organisations with a better opportunity to successfully adopt the RFGQA model as Dickenson et al., (2000) comment that the attempted options to implement Western quality management ideas in Russia have shown limited success. In this context, Rocha-Lona et al. (2014) suggest that the adoption of quality management models, approaches and tools is in function with different organisation aspects, including how mature a company is in terms of degree of knowledge, use, effective deployment and concrete positive results obtained from a quality management system.

\section{Insert Figure 2 in here}

When compared with the MBNQA and Deming Prize models, the analysis indicates that the RFGQA pays more emphasis to all the criteria, except for leadership and business results, which are given a greater weight by the MBNQA. In this sense, it is clear to see that the RFGQA tries to balance the satisfaction of customers with the business results while the MBNQA is a much more results-oriented model. The strong results-oriented assessment of the MBNQA, according to Vokurka et al. (2000), is based on the principle that being an award winner does not guarantee increased profits. Thus the MBNQA criteria give more weight to results. Curiously, the position of the RFGQA in balancing these two criteria is the "middle point" between the MBNQA and EFQM model, as unlike the MBNQA, the EFQM considers more important being a customer-oriented organisation than business results. On the other hand, the RFGQA is less concerned with the more "operational" criteria considered by the Deming Prize, for example, standardisation, quality assurance, maintenance, improvement, future plans and information an analysis.

\subsection{Mapping assessment of the MBNQA, EFQM and Deming Prize models on the RFGQA}

Table 5 summarises, based on the seven common themes defined by Vokurka et al. (2000), Miguel (2001), and Porter and Tanner (2004), how the RFGQA addresses the MBNQA, EFQM and Deming Prize award criteria. 


\section{$\underline{\text { Insert Table } 5 \text { in here }}$}

\subsection{Comparison discussion}

Based on the previous analyses and discussions, the following core differences between the RFGQA and the MBNQA, EFQM and Deming Prize models can be highlighted.

\section{RFGQA and Deming Prize}

While there are some similarities between the RFGQA and Deming Prize's criteria and approaches to business excellence (see Tables 3 and 4), the models can still be considered very different. For example, the Deming Prize gives equal weightings to each of its criteria, suggesting that all of the organisational factors evaluated through it have equal value and thus have to be attended with equal thoroughness. On the other hand, the RFGQA gives priority to business results and customer satisfaction. In addition, the Deming Prize model prioritises its focus on various aspects of TQM while RFGAQ divides its priorities into enablers/capabilities and results as well as into internal and external aspects of an organisation.

Some other differences between these two models include:

1) RFGQA has little focus on company long-term objectives, mainly aiming at current and short-term situations in the business, while the Deming Prize emphasises the consideration and formulation of long-term plans and strategies.

2) The Deming Prize asserts data collection and analysis with a focus on low level processes. For this reason, the Deming Prize can be considered as more devoted to the TQM principles than the RFGQA, which does not reiterate a focus on low level processes.

3) Quality assurance concepts such as quality control audits are thoroughly represented within the Deming Prize's criteria while these are not considered part of the RFGQA's criteria.

4) The Deming Prize's criteria emphasises the delegation of power and training of staff. On the other, although the RFGQA also places importance on the second, it also focuses on encouraging the active participation of executives.

5) The Deming Prize model pays strong attention to the collection and analysis of data to evaluate the current situation of the organisation and make future plans. The RFGQA, on the other hand, lacks of such emphasis and criteria.

6) The Deming Prize model stresses the standardisation of activities and processes as an approach to reduce variability and hence increase quality and efficiency. On the other hand, the RFGQA was developed under the principle that a company has already standardised its processes through the adoption of GOST standards.

7) RFGQA considers as one of its priorities the results accomplished by the organisation in addressing the needs and expectations of its employees. Although the Deming Prize model emphasises the delegation of power to employees as well as the education, training and cooperation among staff, it pays less attention to the results obtained in trying to meet the expectations of its stakeholders.

8) RFGQA is a highly oriented customer-focused model while the Deming Prize does not contain a criterion that emphasises customer satisfaction. 
9) While the RFGQA accentuates the impact of organisational results beyond the direct effect on its stakeholders (i.e. influence on society), the Deming Prize does not emphasises this as a priority.

\section{RFGQA and MBNQA}

In general terms, the MBNQA has more similarities with RFGQA than with the Deming Prize. For instance, the most important criterion for both models is that of business results. This shows the similarity of both models in terms of their business results orientation and the consideration and importance that they place on business results as a key element to achieve excellence.

However there are still some crucial differences between these models, some of these include:

1) Through its business results criterion, the MBNQA has a strong emphasis on supplier performance results. Although the RFGQA encourages the development of an effective partnership with suppliers, it is more concerned with this development rather than with the evaluation and analysis of results obtained from such partnership.

2) The RFGQA gives priority not only to the improvement of products and services but also to their promotion in the market. Thus, the model also considers the marketing function as a crucial component to achieve business excellence. The MBNQA does not emphasise this organisational aspect.

3) While the RFGQA has a strong focus on evaluating the employees' perception of their work in their organisations and the implementation of indicators to monitor this, the MBNQA does not consider this as a priority. It does, however, and similarly as the RFGQA, emphasises employee participation and development.

4) The RFGQA emphasises staff communication within the company, which is aimed at improving the overall quality of work. This approach involves the assessment of top to bottom and bottom to top communication channels and coordination at all levels of the company. The MBNQA model does not include a similar specific criterion.

5) The RFGQA has specific criteria that measure the involvement and use of internal resources such as technologies, infrastructure, materials, etc. to realise the implementation of policies and strategies, as well as the effective implementation of processes. This evaluation of internal resources is not strongly emphasised in the MBNQA model.

6) The RFGQA asserts the results accomplished by the organisation in relation to meeting the needs and expectations of society at local, national and global levels. Thus, it has a strong focus on measuring and assessing the public perception of the company. In the case of the MBNQA, it does not have any specific criteria that address this.

\section{RFGQA and EFQM}

While the RFGQA and the EFQM models are very similar in their structures and criteria as the RFGQA was designed based on the EFQM and hence it adopted many of the EFQM concepts into its core structure, there are still some differences between them. Some of the main differences are as follows:

1) The RFGQA emphasises the role of company executives and top management as agents and facilitators of change and innovation. In the case of the EFQM model, although it seeks the leading role of top management in different activities that include leading total quality, assuring a consistent quality culture, recognition of employees' effort, provision of resources and assistance, involvement with customers and suppliers, and promotion of 
quality outside the organisation, it does not consider company executives and top management as drivers of change and innovation.

2) While the RFGQA sees the rewarding and caring of employees as an organisation's wide responsibility, the EFQM model perceives it as the responsibility of top management.

3) The main difference perceived between the RFGQA and EFQM models lies in the processes criterion. For example, while this criterion in the EFQM model only focuses on the organisational processes, the RFGQA model has a broader scope that also includes products and services. For this reason, this criterion in the RFGQA model, unlike that of the EFQM approach, also includes a specific and detail assessment of how organisations design products and services based on customer expectations. In addition, it also evaluates how products and services are marketed, delivered and serviced after sales. This broader emphasis of the RFGQA, however, deprives it from a more detail view of its internal processes. For example, unlike the EFQM model, it does not evaluate how a company identifies, assesses, set targets, stimulates innovation and examines changes in their business processes.

\section{Conclusions}

The dissolution of the Soviet Union at the beginning of the 1990s resulted in a transition of the newly formed Russian Federation into a market economy as well as its active inclusion into the global economic system. This forced the Russian Government to help national organisations improve the quality of their products and services. The creation of the Russian Federation Government Quality Award (RFGQA) in 1996 was aimed at providing Russian businesses with a tool to improve their products, services, and business practices and in this way increase the competitiveness of their products (Russian Research Institute for Certification JSC, 2014). However, despite the relatively high number of scholar researches dedicated to study and compare various BEMs from countries around the world, see Table 1, studies focused on the Russian Business Excellence Model (i.e. RFGQA) are very limited or non-existent at all. Thus, this paper aimed at reviewing the RFGQA model and comparing its objectives, structure and criteria against the MBNQA, EFQM award and Deming Prize. In this context, the research presented in this paper contributes to the quality management theory by expanding the current knowledge on business excellence models as it is among the very first investigations that have studied the RFGQA model. In practical terms, this research would benefit organisations and managers in Russia as they will be able to acquire a deeper knowledge of the RFGQA, which may facilitate its awareness and implementation.

In general terms, the research indicates that although the RFGQA was designed based on the concept and structure of the EFQM model, there are still considerable differences among them, especially on the broader and more general standpoint of the RFGQA regarding internal business processes. This indicates that the RFGQA model has taken into consideration the current situation and needs as well as the quality maturity level of Russian organisations. In regards to the MBNQA and Deming Prize, the RFGQA finds more differences with these two excellence models than with the EFQM.

Although the Russian Government claims that since 1997 more than 1,100 organisations from 72 regions of the Russian Federation have taken part on the award competition (Russian Research Institute for Certification JSC, 2014b), there is no empirical evidence regarding the benefits (i.e. financial, operational, etc.) that the implementation of RFGQA has brought to Russian organisations, the sustainment of such benefits (if any) and the barriers that organisation have faced during its deployment. Therefore, the conduction of an empirical research considering organisations that have successfully and non-successfully participated 
for the award as well as the implementation teams is suggested as part of the future research agenda to explore these unknown aspects of the RFGQA. Similarly, the comparison analysis performed in this paper was based on contrasting the RFGQA's award descriptors (i.e. objectives and criteria) and the emphasis it places on excellence criteria (i.e. weighting) with those of the MBNQA, EFQM award, and the Deming Prize. Thus, a future research agenda can also include a more thorough comparison by including other comparative dimensions, for example, the usage of the models. This can be achieved by conducting a longitudinal statistical analysis with empirical data that may be collected through focus groups, surveys and structured interviews. This can be supported by a content analysis and data synthesis of the RFGQA based on tabulation of studies characteristics, quality and effects as well as the use of statistical methods for exploring differences between studies and combining their effects.

\section{References}

Adeyemi, A.A., Garza-Reyes, J.A., Lim, M.K., Kumar, V., Rocha-Lona (2014), "An investigation into the challenges of implementing the EFQM Excellence Model", Proceedings of the $24^{\text {th }}$ International Conference on Flexible Automation and Intelligent Manufacturing (FAIM), San Antonio, TX, US, 20-23 May.

Briner, R. B., Denyer, D. (2012), Systematic review and evidence synthesis as a practice and Scholarship tool, Handbook of evidence-based management: Companies, classrooms and research, 112-129.

Dahlgaard, J.J., Kristensen, K. and Kanji, G.K. (1998), Fundamentals of Total Quality Management: process analysis and improvement, Chapman \& Hall, London.

Dickenson, R.P., Campbell, D.R., Azarov, V.N. (2000), "Quality management implementation in Russia: strategies for change", International Journal of Quality \& Reliability Management, Vol. 17, No. 1, pp. 66-82.

EFQM (2013), "EFQM excellence award”, available at: http://www.efqm.org/en/?TabId=154 (accessed 29 June 2013).

EFQM (2014), “The EFQM excellence model”, available at: http://www.efqm.org/the-efqmexcellence-model (accessed 10 August 2014).

European Commission (2014), "Countries and Regions - Russia", available at: http://ec.europa.eu/trade/policy/countries-and-regions/countries/russia/ (accessed 11 August 2014).

Everett, E., Corbett, L., Flores, B., Harrison, N., Lee, T., Rho, B., Ribera, J., Samson, D., Westbrook, R. (1997), "An international study of quality improvement approaches and firm performance", International Journal of Operations and Production Management, Vol. 17, No. 9, pp. 842-874.

Ghobadian, A., Woo H.S. (1996), "Characteristics, benefits and shortcomings of four major quality awards", International Journal of Quality \& Reliability Management, Vol. 13, No. 2, pp. 10-14.

GOST (2014), "GOST-R Certification in Russia. Russian certification. Certificate of conformity in Russia. Goststandart", available at: http://www.gost-r.info/ (accessed 9 August 2014).

Grigg, N.P., Mann, R.S. (2008a), "Review of the Australian business excellence framework: a comparison of national strategies for designing, administering and promoting business excellence frameworks", Total Quality Management and Business Excellence, Vol. 19, No. 11, 1173-1188. 
Grigg, N.P. and Mann, R.S. (2008b), "Promoting excellence: an international study into creating awareness of Business Excellence models", The TQM Magazine, Vol. 20 No. 3, pp. 233-48.

Jayamaha, N.P., Grigg, N.P., Mann, R.S. (2011), "Empirical analysis of the Baldrige criteria as both an organisational performance measure and a theoretical model", Measuring Business Excellence, Vol. 15, No. 1, pp. 20-33.

JUSE (2014), “The Deming prize”, available at: http://www.juse.or.jp/e/deming/92/ (accessed on 15 August 2015).

Kim, D.Y., Vinod, K., Murphy, S.A. (2010), “European Foundation for Quality Management business excellence model: an integrative review and research agenda", International Journal of Quality \& Reliability Management, Vol. 27, No. 6, pp. 68 -701.

Mavroidis, V., Toliopoulou, S., Agoritsas, C. (2007), “A comparative analysis and review of National Quality Awards in Europe: development of critical success factors", The TQM Magazine, Vol. 19, No. 5, pp. 454-467

Miguel, P.A.C. (2001), "Comparing the Brazilian National Quality Award with some of the major prizes", The TQM Magazine, Vol. 13, No. 4, pp. 260-72.

Mohammad, M., Mann, R., Grigg, N., Jürgen, P. (2011), "Business excellent model: an overarching framework for managing and aligning multiple organisational improvement initiatives", Total Quality Management \& Business Excellence, Vol. 22, No. 11, pp. 1213-1236.

NIST (2014), "2013-2014 criteria for performance excellence", available at: http://www.nist.gov/baldrige/publications/business nonprofit criteria.cfm (accessed 12 August 2014)

Oakland, J. (2001), Total organisational excellence: achieving world-class performance, 2nd edition, Butterworth-Heinemann, Oxford.

Porter, L. and Tanner, S. (1996), Assessing business excellence, 1st edition, ButterworthHeinemann, Oxford.

Porter, L.J. and Tanner, S.J. (2004), Assessing business excellence: a guide to business excellence and self-assessment, 2nd Edition, Elsevier, Oxford.

Puay, S., Tan, T., Xie, M., Goh, T. (1998), "A comparative study of nine national quality awards", The TQM Magazine, Vol. 10, No. 1, pp. 30-39.

Rebrin, I. (2004), "History and evolution of quality control systems", available at: http://www.aup.ru/books/m93/1 3.htm (accessed 9 August 2014).

Rocha-Lona, L., Garza-Reyes, J.A., Soriano-Meier, H., Peacock, T., Forrester, P.L. (2009), "Developing a business improvement strategy based on self-assessments using the EFQM model", Proceeding of the $19^{\text {th }}$ International Conference on Flexible Automation and Intelligent Manufacturing (FAIM), Middlesbrough, UK, 6-9 July, pp. 1234-1242.

Rocha-Lona, L., Garza-Reyes J.A., Kumar, V. (2013), Building quality management systems: selecting the right methods and tools, Productivity Press, CRC Press, Taylor \& Francis, Boca Raton, FL.

Rosstandart, (2014), Federal agency for technical regulation and metrology (Rosstandart), 1 st edition, VNIIS, Moscow.

Rousseau, D.M. (2012). The Oxford handbook of evidence-based management. Oxford University Press Inc., New York. 
Russian Research Institute for Certification JSC (2014a), "Why to compete for the award?", available at: http://www.vniis.org/russianqualityaward (accessed 9 August 2014).

Russian Research Institute for Certification JSC (2014b), "Model for the Russian Government quality award", available at: http://www.vniis.org/russianqualityaward/modelRQA (accessed 13 August 2014).

Sampaio, P., Saraiva, P., Monteiro, A. (2012), "A comparison and usage overview of business excellence models", The TQM Journal, Vol. 24, No. 2, pp.181-200.

Saunders, M., Mann, R., Grigg, N. (2008), "Review processes for improving business excellence frameworks", International Journal of Quality \& Reliability Management, Vol. 25, No. 9, pp. 928-942.

Sharma, A.K., Talwar, B. (2007), "Evolution of "Universal Business Excellence Model" incorporating Vedic philosophy", Measuring Business Excellence, Vol. 11, No. 3, pp. 4 -20 .

Talwar, B. (2009), "Comparative study of core values of excellence models vis-à-vis human values", Measuring Business Excellence, Vol. 13, No. 4, pp. 34-46.

Talwar, B. (2011a), "Business excellence models and the path ahead", The TQM Journal, Vol. 23, No. 1, pp. 21-35.

Talwar, B. (2011b), "Comparative study of framework, criteria and criterion weighting of excellence models", Measuring Business Excellence, Vol. 15, No. 1, pp. 49-65.

Tan, K. (2002), "A comparative study of 16 National Quality Awards", The TQM Magazine, Vol. 14, No. 3, pp.165-71.

Tan, K., Wong, M., Mehta, T., Hsien, H. (2003), "Factors affecting the Development of National Quality Awards", Measuring Business Excellence, Vol. 7, No. 3, pp.37-45.

Vokurka, R., Stading, G., Brazeal, J. (2000), “A comparative analysis of National and Regional Quality Awards”, Quality Progress, Vol. 33, No. 8, pp.41-49. 


\begin{tabular}{|c|c|c|}
\hline Vokurka et al. (2000) & $\begin{array}{l}\text { Malcolm Baldrige National } \\
\text { Quality Award (MBNQA), } \\
\text { European Foundation for Quality } \\
\text { Management (EFQM) Award, } \\
\text { Deming Prize, Canadian Quality } \\
\text { Award, Australian Quality } \\
\text { Award }\end{array}$ & $\begin{array}{l}\text { Compares some characteristics including } \\
\text { quality principles, assessment criteria and } \\
\text { procedure }\end{array}$ \\
\hline Miguel (2001) & $\begin{array}{l}\text { MBNQA, EFQM Award, } \\
\text { Deming Prize, Canadian Quality } \\
\text { Award, Australian Quality } \\
\text { Award, National Quality Award } \\
\text { of Brazil }\end{array}$ & $\begin{array}{l}\text { Outlines their criteria for performance } \\
\text { excellence and some descriptors, describes } \\
\text { their application procedure, evaluation process, } \\
\text { and the scoring methodology. It performs a } \\
\text { comparison between the major awards and the } \\
\text { Brazilian programme }\end{array}$ \\
\hline $\operatorname{Tan}(2002)$ & $\begin{array}{l}\text { Quality Awards from: Argentina, } \\
\text { Aruba, Australia, Chile; Egypt, } \\
\text { EFQM (Europe) EFQM for } \\
\text { SMEs, Hong Kong, Deming } \\
\text { (Japan), MBNQA (US), } \\
\text { Mauritius, Israel, Malaysia, } \\
\text { Singapore, South Africa, Sri } \\
\text { Lanka }\end{array}$ & $\begin{array}{l}\text { Discusses their similarities, differences and } \\
\text { strengths }\end{array}$ \\
\hline Tan et al. (2003) & $\begin{array}{l}53 \text { BEMs/National Quality } \\
\text { Awards (NQAs) }\end{array}$ & $\begin{array}{l}\text { Superficial comparison of } 53 \text { BEMs/NQAs } \\
\text { with MBNQA, EFQM or EFQM for SMEs; } \\
\text { elements of ISO9000:2000; ISO 14000; and } \\
\text { own framework }\end{array}$ \\
\hline Mavroidis et al. (2007) & $31 \mathrm{BEMs/NQAs} \mathrm{in} \mathrm{Europe}$ & $\begin{array}{l}\text { Compares } 31 \text { NQAs of the European Union by } \\
\text { means of their substantial differentiation from } \\
\text { the EFQM model }\end{array}$ \\
\hline Talwar (2009) & 16 BEMs/NQAs & $\begin{array}{l}\text { Compares the core values (i.e. customer focus, } \\
\text { continuous learning, innovation and } \\
\text { improvement, employee involvement, etc.) to } \\
\text { "human values enshrined in ancient religious } \\
\text { philosophies and identified by social scientists } \\
\text { as a spiritual way of working" (Talwar, 2009) }\end{array}$ \\
\hline Kim et al. (2010) & EFQM, MBQNA, ISO 9000 & $\begin{array}{l}\text { Discusses similarities and differences among } \\
\text { themselves and TQM }\end{array}$ \\
\hline Talwar (2011a) & $81 \mathrm{BEMs} / \mathrm{NQAs}$ & $\begin{array}{l}\text { Superficial comparison of } 81 \text { BEMs/NQAs } \\
\text { with Deming Prize, MBNQA, EFQM and own } \\
\text { framework }\end{array}$ \\
\hline Talwar (2011b) & $\begin{array}{l}\text { Deming Prize, MBNQA, EFQM } \\
\text { and other } 17 \text { BEMs/NQAs }\end{array}$ & $\begin{array}{l}\text { Comparison in terms of their framework, } \\
\text { criteria and criterion weighting }\end{array}$ \\
\hline Sampaio et al. (2012) & $\begin{array}{l}\text { Deming Prize, MBNQA, EFQM } \\
\text { and the Iberoamerican Model for } \\
\text { Excellence in Management }\end{array}$ & $\begin{array}{l}\text { Comparison focuses on their criteria, their } \\
\text { underpinning structures and their criteria } \\
\text { weighting of the quality awards }\end{array}$ \\
\hline
\end{tabular}

Table 1. Research undertaken to compare different BEMs

Table 2. Award descriptors 


\begin{tabular}{|c|c|c|c|c|}
\hline & MBNQA & EFQM & Deming Prize & RFGQA \\
\hline Objectives & $\begin{array}{l}\text { - To help improve } \\
\text { performance } \\
\text { practices }^{(\mathrm{a}, \mathrm{b})} \\
\text { - To facilitate } \\
\text { communication } \\
\text { and sharing of best } \\
\text { practices among } \\
\text { US } \\
\text { organisations }{ }^{(\mathrm{a}, \mathrm{b}, \mathrm{c})} \\
\text { - To serve as a } \\
\text { working tool for } \\
\text { understanding and } \\
\text { managing } \\
\text { performance, } \\
\text { planning, training } \\
\text { and } \\
\text { assessment } \\
\end{array}$ & $\begin{array}{l}\text { - To stimulate and } \\
\text { assist European } \\
\text { organisations in } \\
\text { improving } \\
\text { customer and } \\
\text { employee } \\
\text { satisfaction, } \\
\text { impact on society } \\
\text { and business } \\
\text { results }{ }^{(\mathrm{a}, \mathrm{b}, \mathrm{d})} \\
\text { - To support } \\
\text { European } \\
\text { managers' efforts } \\
\text { to initiate total } \\
\text { quality } \\
\text { management and } \\
\text { achieve global } \\
\text { competitive } \\
\text { advantage }{ }^{(\mathrm{a}, \mathrm{b}, \mathrm{d})} \\
\text { - To enhance the } \\
\text { position of } \\
\text { European industry } \\
\text { and commerce by } \\
\text { strengthening the } \\
\text { strategic role of } \\
\text { quality in } \\
\text { corporations } \\
\text { (e) }\end{array}$ & $\begin{array}{l}\text { - To evaluate and } \\
\text { recognise methods } \\
\text { of company-wide } \\
\text { quality control for } \\
\text { Japanese } \\
\text { businesses } \\
\text { - To,b,f) } \\
\text { companies that } \\
\text { have successfully } \\
\text { applied company- } \\
\text { wide quality } \\
\text { control based on } \\
\text { statistical control, } \\
\text { and are likely to } \\
\text { keep it up in the } \\
\text { future }\end{array}$ & $\begin{array}{l}\text { - To provide } \\
\text { Russian } \\
\text { businesses with a } \\
\text { tool to improve } \\
\text { their products, } \\
\text { services, and } \\
\text { business practices } \\
\text { and increase the } \\
\text { competitiveness of }^{(\mathrm{h})} \\
\text { their products }^{\text {a }}\end{array}$ \\
\hline Criteria & $\begin{array}{l}\text { 1. Leadership } \\
\text { 2. Strategic } \\
\text { planning } \\
\text { 3. Customer and } \\
\text { market } \\
\text { focus } \\
\text { 4. Information and } \\
\text { analysis } \\
\text { 5. Human resource } \\
\text { focus } \\
\text { 6. Process } \\
\text { management } \\
\text { 7. Business results }\end{array}$ & $\begin{array}{l}\text { 1. Leadership } \\
\text { 2. Policy and } \\
\text { strategy } \\
\text { 3. People } \\
\text { management } \\
\text { 4. Resources } \\
\text { 5. Process } \\
\text { 6. Customer } \\
\text { satisfaction } \\
\text { 7. People } \\
\text { satisfaction } \\
\text { 8. Impact on society } \\
\text { 9. Business results }\end{array}$ & $\begin{array}{l}\text { 1. Policies (hoshin) } \\
\text { 2. Organisation and } \\
\text { its operations } \\
\text { 3. Information } \\
\text { 4. Standardisation } \\
\text { 5. Human resources } \\
\text { 6. Quality assurance } \\
\text { 7. Maintenance } \\
\text { 8. Improvement } \\
\text { 9. Effects } \\
\text { 10. Future plans }\end{array}$ & $\begin{array}{l}\text { 1. Leading role of } \\
\text { management } \\
\text { 2. Personnel } \\
\text { 3. Quality policy } \\
\text { and strategy of } \\
\text { organisation } \\
\text { 4. Partnership and } \\
\text { resources } \\
\text { 5. Processes, } \\
\text { products and } \\
\text { services } \\
\text { 6. Personnel } \\
\text { satisfaction } \\
\text { 7. Customer } \\
\text { satisfaction with } \\
\text { product (service) } \\
\text { quality } \\
\text { 8. Organisation } \\
\text { impact on society } \\
\text { 9. Results of } \\
\text { organisation } \\
\text { activity }\end{array}$ \\
\hline \multicolumn{5}{|c|}{ Legend } \\
\hline $\begin{array}{l}\text { (a) Vokurka et } \\
\text { (1996); (f) JUS } \\
(2014)\end{array}$ & (g) Porter and $\mathrm{Ta}$ & (2004); (h) Russi & search Institute fo & $\begin{array}{l}\text { dian and Woo } \\
\text { rtification JSC }\end{array}$ \\
\hline
\end{tabular}

Table 3. Models criteria 


\begin{tabular}{|l|c|c|c|c|}
\hline \multicolumn{1}{|c|}{ Criteria } & MBNQA & EFQM & Deming Prize & RFGQA \\
\hline Leadership & $\times$ & $\times$ & $\times$ & $\times$ \\
\hline Policy and Strategy & $\times$ & $\times$ & & $\times$ \\
\hline People Management & $\times$ & $\times$ & $\times$ & $\times$ \\
\hline Resources & & $\times$ & & $\times$ \\
\hline Processes & $\times$ & $\times$ & $\times$ & $\times$ \\
\hline Customer Satisfaction & $\times$ & $\times$ & & $\times$ \\
\hline People Satisfaction & & $\times$ & & $\times$ \\
\hline Impact on Society & & $\times$ & $\times$ & \\
\hline Business Results & $\times$ & $\times$ & $\times$ & \\
\hline Information and Analysis & $\times$ & & $\times$ & \\
\hline Standardisation & & & $\times$ & \\
\hline Quality Assurance & & & $\times$ & \\
\hline Maintenance & & & \\
\hline Improvement & & & & \\
\hline Future Plans & & & & \\
\hline
\end{tabular}


Table 4. Common themes comparison

\begin{tabular}{|c|c|c|c|c|}
\hline & RFGAQ & MBNQA & EQA & Deming Prize \\
\hline Leadership & $\begin{array}{l}\text { Active participation } \\
\text { by company } \\
\text { management and } \\
\text { executives in } \\
\text { company activities. } \\
\text { Motivation of staff, } \\
\text { support, inspiration }\end{array}$ & $\begin{array}{l}\text { Executive, company } \\
\text { and community } \\
\text { leadership }\end{array}$ & $\begin{array}{l}\text { Inspiration, support } \\
\text { and promotion of } \\
\text { total quality } \\
\text { management }\end{array}$ & $\begin{array}{l}\text { Policy, organisation } \\
\text { and helpful } \\
\text { supervision }\end{array}$ \\
\hline $\begin{array}{l}\text { Strategy and } \\
\text { Planning }\end{array}$ & $\begin{array}{l}\text { Systematic } \\
\text { planning aimed at } \\
\text { satisfying customer } \\
\text { expectations }\end{array}$ & $\begin{array}{l}\text { Strategic direction, } \\
\text { plan development, } \\
\text { plan } \\
\text { deployment and } \\
\text { performance } \\
\text { tracking }\end{array}$ & $\begin{array}{l}\text { Product of policy } \\
\text { and } \\
\text { strategy }\end{array}$ & $\begin{array}{l}\text { Future plans, quality } \\
\text { control initiatives } \\
\text { and policy focus }\end{array}$ \\
\hline Customers Focus & $\begin{array}{l}\text { Companies } \\
\text { performance } \\
\text { indicators aimed at } \\
\text { increasing customer } \\
\text { satisfaction }\end{array}$ & $\begin{array}{l}\text { Market } \\
\text { requirements, } \\
\text { customer } \\
\text { relationships and } \\
\text { satisfaction }\end{array}$ & $\begin{array}{l}\text { Measurement of } \\
\text { customer } \\
\text { satisfaction }\end{array}$ & $\begin{array}{l}\text { Service activities } \\
\text { and customer } \\
\text { relationships }\end{array}$ \\
\hline People Focus & $\begin{array}{l}\text { Improvement of } \\
\text { employee } \\
\text { perception and } \\
\text { satisfaction }\end{array}$ & $\begin{array}{l}\text { Human resource } \\
\text { development } \\
\text { and participatory } \\
\text { environment }\end{array}$ & $\begin{array}{l}\text { Release of full } \\
\text { potential through } \\
\text { people } \\
\text { management. }\end{array}$ & $\begin{array}{l}\text { Training and } \\
\text { motivation of } \\
\text { skilled labour } \\
\text { personnel. }\end{array}$ \\
\hline $\begin{array}{c}\text { Processes } \\
\text { Management }\end{array}$ & $\begin{array}{l}\text { Systematic } \\
\text { planning and } \\
\text { process } \\
\text { management, } \\
\text { constant process } \\
\text { maintenance }\end{array}$ & $\begin{array}{l}\text { Process design, } \\
\text { implementation, } \\
\text { management and } \\
\text { improvement }\end{array}$ & $\begin{array}{l}\text { Identification, } \\
\text { management, } \\
\text { review and } \\
\text { improvement }\end{array}$ & $\begin{array}{l}\text { Standardisation, } \\
\text { quality assurance, } \\
\text { maintenance and } \\
\text { improvement. }\end{array}$ \\
\hline $\begin{array}{l}\text { Suppliers and } \\
\text { Partnerships }\end{array}$ & $\begin{array}{l}\text { Aim at good } \\
\text { relation with and } \\
\text { suppliers }\end{array}$ & $\begin{array}{l}\text { Improvement of } \\
\text { partnering } \\
\text { process and } \\
\text { evaluation of } \\
\text { supplier } \\
\text { performance }\end{array}$ & $\begin{array}{l}\text { Leadership } \\
\text { involvement } \\
\text { with and } \\
\text { management of } \\
\text { supplier resource }\end{array}$ & $\begin{array}{l}\text { Vendor training and } \\
\text { associations of } \\
\text { related } \\
\text { companies }\end{array}$ \\
\hline Results & $\begin{array}{l}\text { Stakeholder } \\
\text { satisfaction, good } \\
\text { impact on society, } \\
\text { success based on } \\
\text { customer reflection }\end{array}$ & $\begin{array}{l}\text { Customer, financial, } \\
\text { human resource, } \\
\text { supplier, operational } \\
\text { and competitive }\end{array}$ & $\begin{array}{l}\text { Objective } \\
\text { achievement, } \\
\text { stakeholder } \\
\text { satisfaction, } \\
\text { financial success } \\
\text { and impact on } \\
\text { society }\end{array}$ & $\begin{array}{l}\text { Quality, delivery, } \\
\text { cost, } \\
\text { profit, safety and } \\
\text { environmental } \\
\text { effects of quality } \\
\text { control }\end{array}$ \\
\hline
\end{tabular}


Table 5. Mapping assessment

\section{RFGQA}

EFQM

Deming Prize

MBNQA

1. Leading role of company executives - How company management of all levels decides the mission of the company; how it manages the strategy of company development and helps it develop, how values are formed which are essential in achieving long-term success, with self-example and events; how management is involved in the development and implementation of a company's managerial systems

1a - Settings by the company executives the purpose of the organisation, development strategy, values and ethics, personal examples to

$1.1,1.2$ 2.4 1.2

demonstrate its commitment to quality culture

$1 \mathrm{~b}$ - Participation of company executives in ensuring the development, implementation and

$\mathrm{N} / \mathrm{A}$

1.1

continuous improvement of the organisation's managerial systems

1c - Executives participate in working with customers, partners and other external stakeholders

1d - Motivation, support and encouragement of company staff by its executives

1e - Identify and support of innovation and change in the organisation by its executives

2. Policy and strategy within an organisation in field of quality - How an organisation implements its mission and development strategy by targeting stakeholder needs, development policies, plans, goals and processes

$2 \mathrm{a}$ - Identify existing and

future needs and

expectations of

stakeholders parties in

$8.9,8.10$

N/A

order to develop policies

and strategies

$2 \mathrm{~b}$ - Using information

obtained from

measurements studies, cognitive and creative activities for the

development of policies and strategies

2c - Development, analysis and improvement of policies and strategies

$2 \mathrm{~d}$ - Deployment and execution of policies and strategies within the
1.5

N/A

N/A 


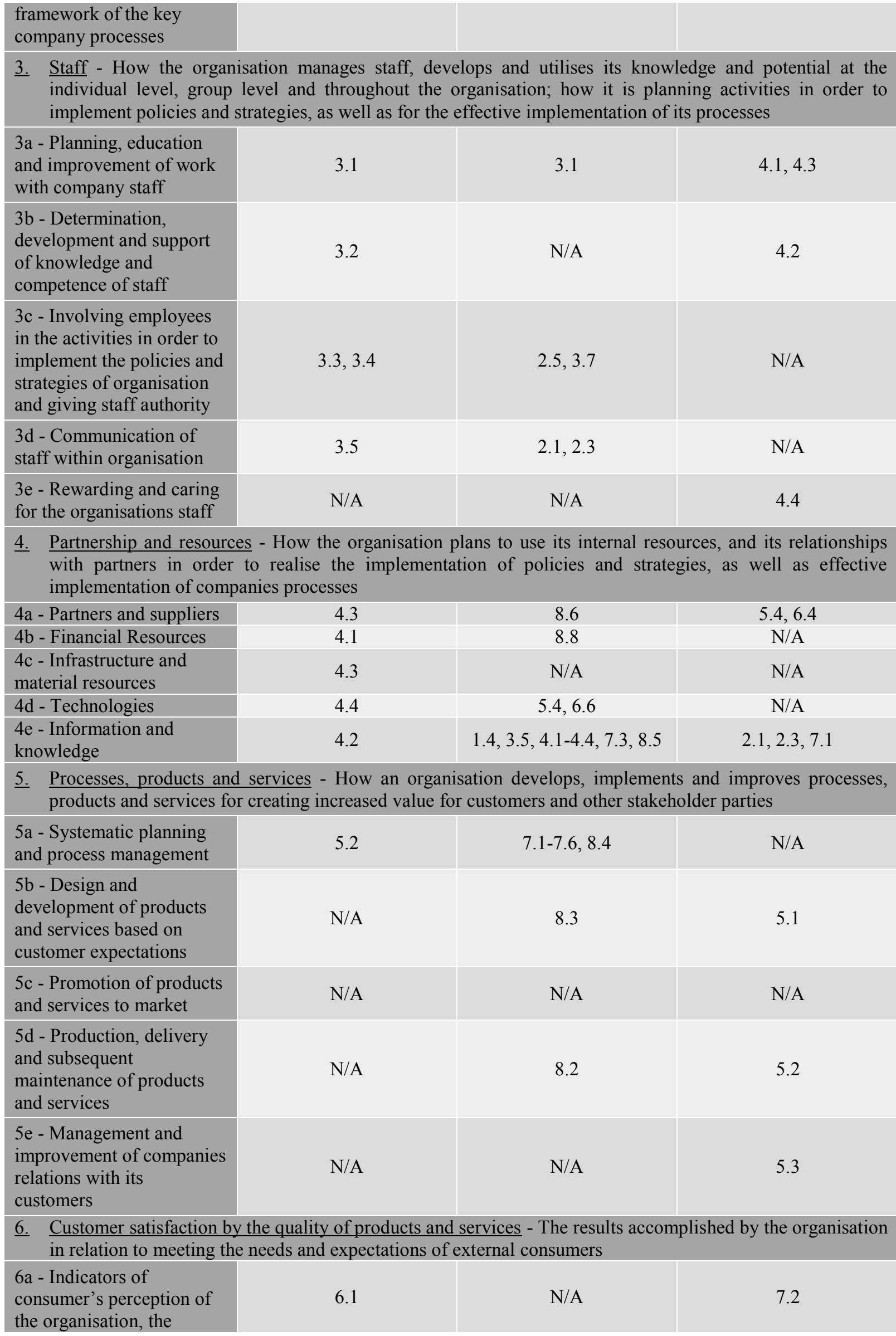




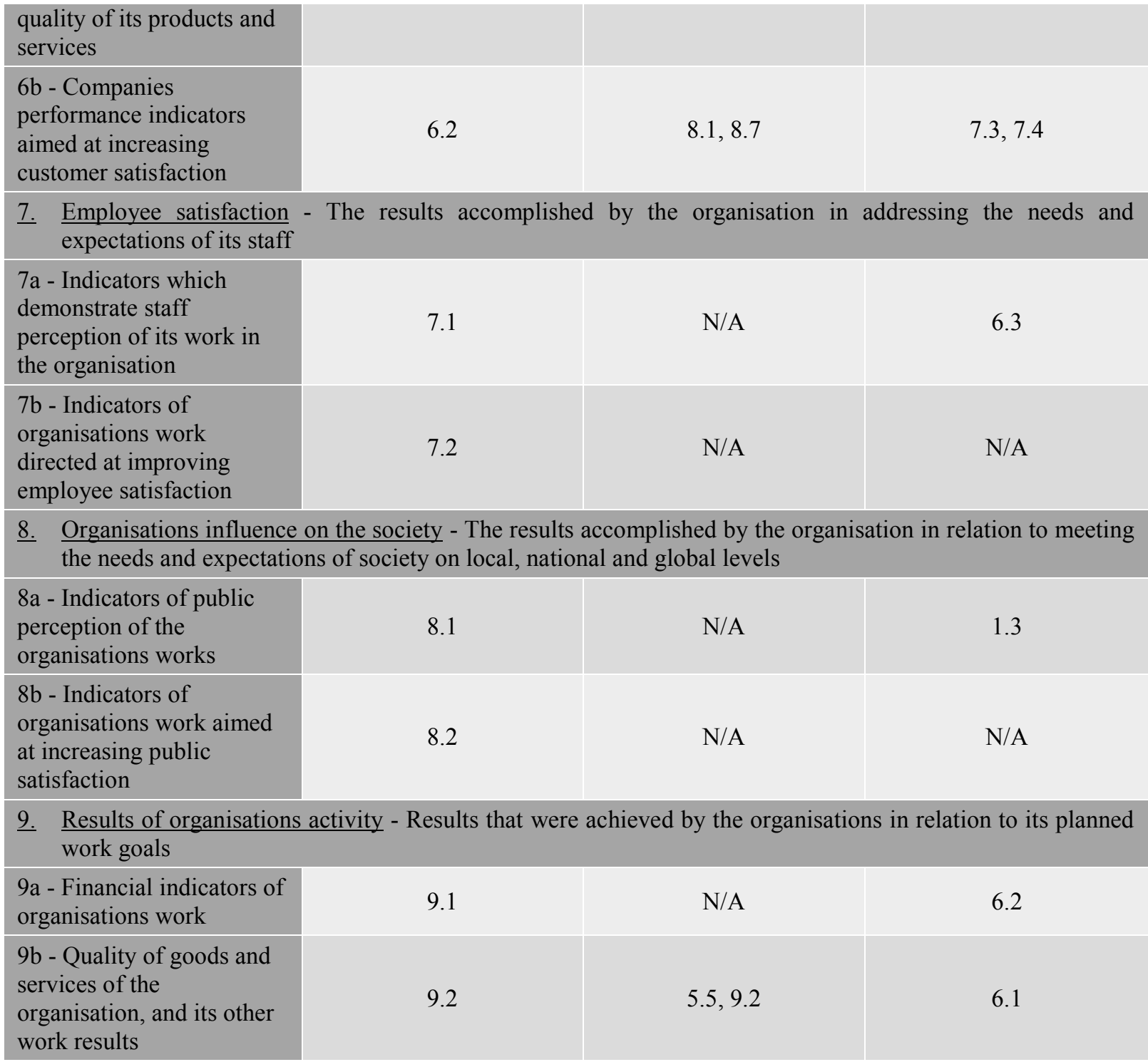




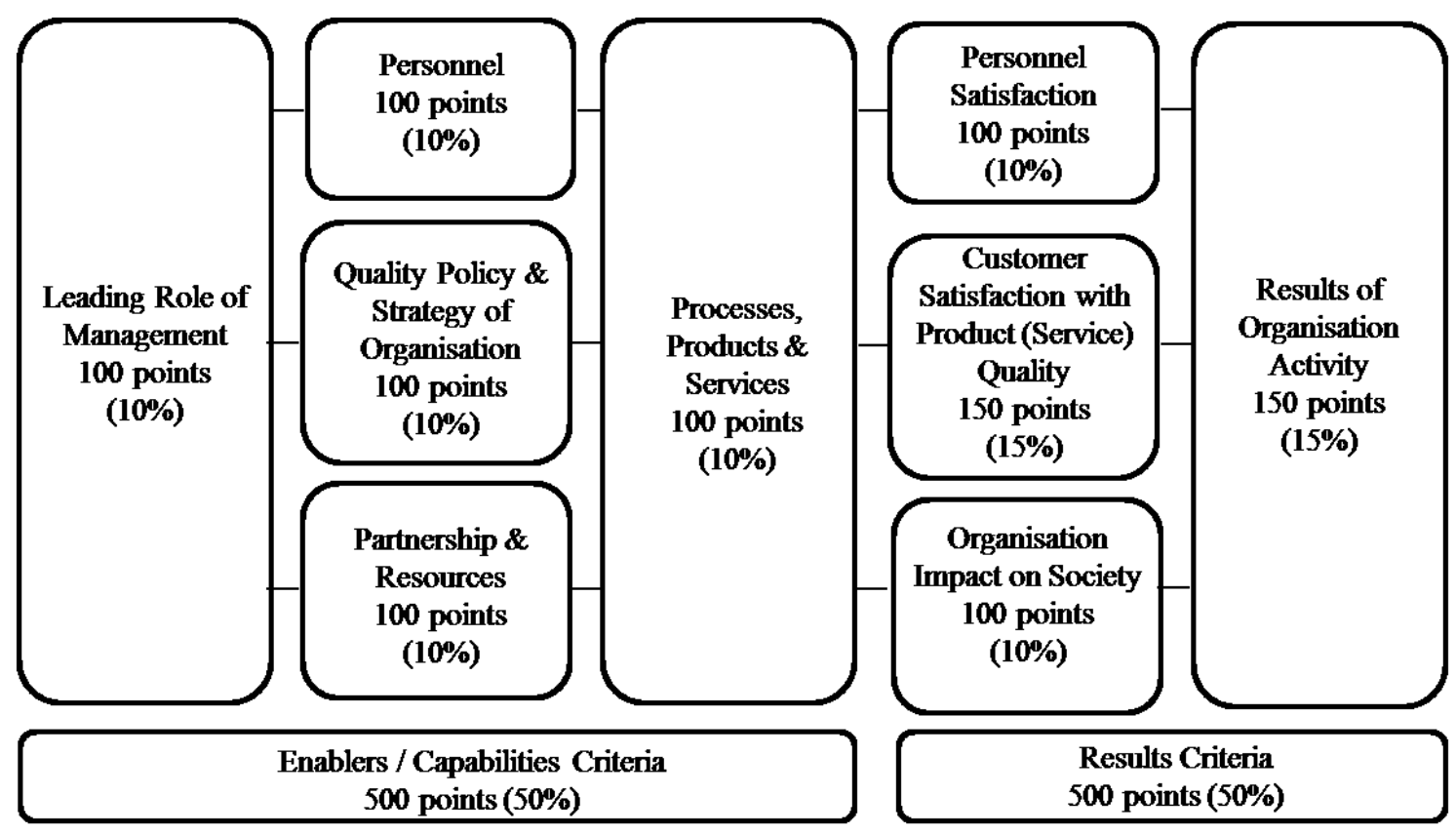

Figure 1. RFGQA’ structure

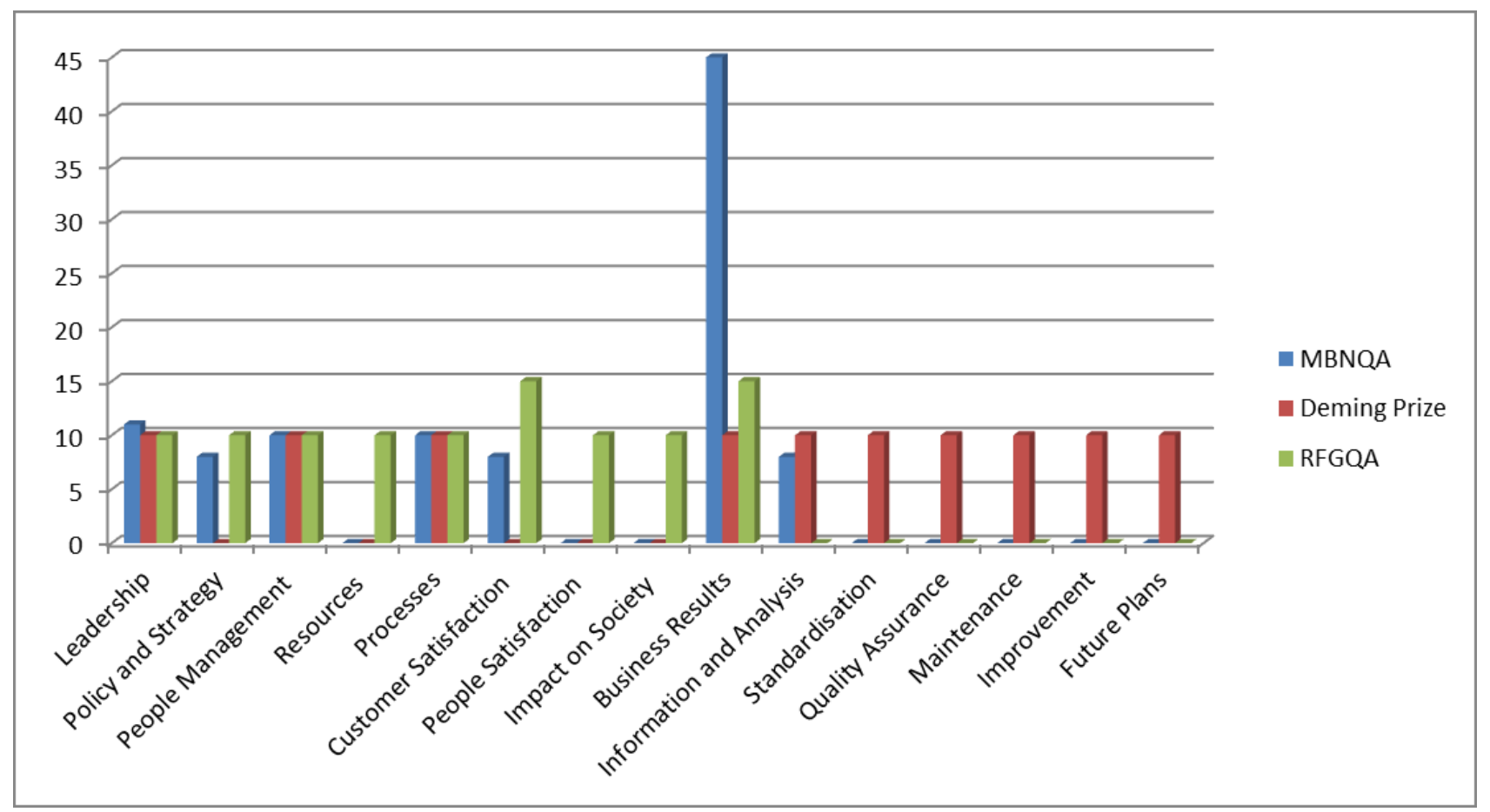

Figure 2. Emphasis on criteria - comparison 